\title{
Accurate identification of atypical Staphylococcus chromogenes plasma-clotting strains causing bovine mastitis
}

\section{Pedro Avellar-Costa ${ }^{1}$ Danielle Cabral dos Santos ${ }^{1}$ Carla Christine Lange $^{2}$ Marinella Silva Laport ${ }^{1}$ Maria Aparecida Vasconcelos Paiva Brito ${ }^{2}$ Ciro César Rossi ${ }^{1}$ Marcia Giambiagi-deMarval $^{1^{*}}$ (D)}

\footnotetext{
${ }_{1}^{1}$ Instituto de Microbiologia Paulo de Góes, Universidade Federal do Rio de Janeiro (UFRJ), Rio de Janeiro, RJ, Brasil.

${ }^{2}$ Embrapa Gado de Leite, Juiz de Fora, MG, Brasil. E-mail: marciagm@micro.ufrj.br. "Corresponding author.
}

ABSTRACT: We compared the potential of routine techniques used for the identification of Staphylococcus species, aiming to evaluate their accuracy in the detection of 43 Staphylococcus chromogenes strains isolated from bovine mastitis that, despite being a coagulase-negative species, are able to clot plasma. These strains could be mistakenly suspected to be $S$. aureus and lead to an unappropriated treatment of the disease. MALDI-TOF, PCR-RFLP of the chaperonine gene groEL, and sequencing of the $16 S \mathrm{rRNA}$ and elongation factor Tu gene tuf were employed. Results from the four methods were coincident for only half of the strains because of the low accuracy of the groEL PCR-RFLP (51.2\% accuracy). Even though all the sequencing results were identical, the high accuracy of the MALDI-TOF results (97.7\% accuracy, with only one strain misidentified) encourage the use of this technique, since it does not require laborious sample preparation, being fast and simple to perform. Key words: Staphylococcus chromogenes, mastitis, MALDI-TOF, tuf, groEL.

Identificação acurada de cepas atípicas de Staphylococcus chromogenes que coagulam o plasma envolvidas com mastite bovina

RESUMO: Nós comparamos o potencial de técnicas rotineiras utilizadas para a identificação de espécies de Staphylococcus, com o objetivo de avaliar a acurácia delas na detecção de 43 isolados de Staphylococcus chromogenes envolvidos com mastite bovina que, apesar de ser uma espécie coagulase-negativa, são capazes de coagular o plasma. Essas cepas poderiam ser erroneamente suspeitas de serem $S$. aureus e levarem a um tratamento não adequado da doença. MALDI-TOF, PCR-RFLP do gene da chaperonina groEL e sequenciamento do gene do $r R N A 16 S$ e do gene do fator de elongação Tu, tuf, foram avaliados. Os resultados dos quatro métodos foram coincidentes para apenas metade das cepas, devido à baixa precisão da PCR-RFLP com groEL (51,2\% de acurácia). Apesar de todos os resultados do sequenciamento serem idênticos, a alta precisão dos resultados do MALDI-TOF (97,7\% de acurácia, com apenas uma cepa identificada incorretamente) encoraja o uso dessa técnica, pois, não requer preparação laboriosa de amostras, sendo rápida e simples de executar.

Palavras-chave: Staphylococcus chromogenes, mastite, MALDI-TOF, tuf, groEL.

Staphylococcus aureus, the major pathogen from its genus, causes a wide range of clinical infections in human beings and animals (TONG et al., 2015). Discrimination between $S$. aureus from most staphylococci is primarily made by evaluating its ability to produce the enzyme coagulase, which promotes clotting of plasma. This activity is the foundation of routine identification tests and helps in the differentiation between $S$. aureus and coagulase-negative staphylococci (CoNS), which were long considered as harmless environmental contaminants, but are emerging as important opportunist pathogens (BECKER et al., 2014). However, our group has recently described Staphylococcus chromogenes strains, isolated from dairy animals with mastitis, that are surprisingly capable of clotting plasma, besides being a coagulase-negative species (SANTOS et al., 2016). Among CoNS, Staphylococcus chromogenes is one of the major pathogens involved with mastitis in dairy animals (VANDERHAEGHEN et al., 2014), while $S$. aureus is the major coagulase-positive pathogen causing the same disease (BARKEMA et al., 2006). For a long time overlooked, S. chromogenes has also been isolated from hospitals and other healthcare facilities (CATANO et al., 2012; ZEMOURI et al., 2017; ZHENZHEN et al., 2018), in addition to being shown colonizing HIV-positive patients (BACK-BRITO et al., 2011), and causing bloodstream infections in patients with AIDS (ADEYEMI et al., 2010). Then, the coagulase- 
positive phenotype of $S$. chromogenes shown by our group can easily lead to misidentification and inappropriate treatment of the disease caused by them.

Aiming to search for accurate methods to identify strains showing atypical results in the coagulation assays, we estimated the identification potential of four different techniques: MatrixAssisted Laser Desorption Ionization-Times of Flight Mass Spectometry (MALDI-TOF), PCR-restriction fragment length polymorphism (PCR-RFLP) of the chaperonine gene groEL, and DNA sequencing of the 16S rRNA and elongation factor Tu gene tuf.

The $S$. chromogenes strains $(\mathrm{n}=43)$ studied in our previous research (SANTOS et al., 2016), were first analyzed in triplicate by MALDITOF as described before (TOMAZI et al., 2014). Mass spectral data were collected within the $\mathrm{m} / \mathrm{z}$ range of 2,000 to 20,000, and the data were acquired and analyzed using the FlexControl software 3.3 (Bruker Daltonics, MA, USA). A PCR-RFLP of the groEL gene strategy, standardized by our group to differentiate several relevant Staphylococcus species (SANTOS et al., 2008), was then performed. The identification data obtained were compared to those from the previous DNA sequencing of the $16 \mathrm{~S}$ rRNA and tuf genes (SANTOS et al., 2016).

Only $23(51.2 \%)$ strains displayed coincident results for all the four methods (Figure 1), indicating strain variation, as previously observed (SANTOS et al., 2016). However, because all results from DNA sequencing were identical, all strains were confirmed as being $S$. chromogenes. All strains had MALDI-TOF scores $\geq 2.3$, indicating reliable identification of the species. The groEL PCR-RFLP was the less accurate (51.2\% accuracy) method, as 21 (48.8\%) strains were either identified as Staphylococcus caprae $(\mathrm{n}=20)$ or undetermined. The MALDI-TOF had 97.7\% accuracy, with only one strain misidentified. This result is consistent with the high accuracy of the technique reported for several Staphylococcus species obtained from different origins, such as clinical, food samples and plants (DUBOI et al., 2010), domestic dogs (SILVA et al., 2015) and domestic cats (ROSSI et al., 2017).

For being faster, cost-effective and easier to perform, allowing diagnosis using intact cells or cell extracts, this technique is an emergent identification method (ZHU et al., 2015). The equipment is available in most major university centers and many large hospitals in Brazil and the cost per analysis of each sample is less than fifty cents of dollar. In addition, the MALDI-TOF analysis service is offered by international companies, such as MIDI Labs (USA, http://midilabs.com) and BIOTECON Diagnostics (Germany, http://www.bc-diagnostics.com).

Our results, together with the aforementioned advantages, encourage the use

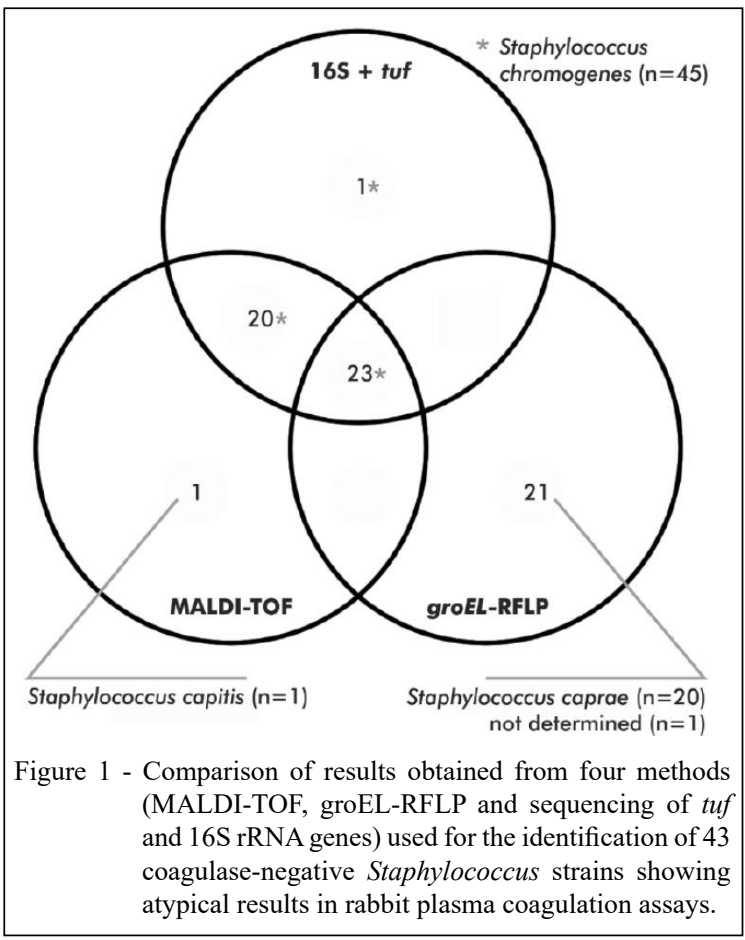

Ciência Rural, v.49, n.6, 2019. 
of MALDI-TOF as the identification method for Staphylococcus species isolated from cows with mastitis even for atypical $S$. chromogenes strains that are able to clot plasma and are circulating in Brazilian farms.

\section{ACKNOWLEDGMENTS}

The authors are grateful for the financial support from Fundação de Amparo à Pesquisa do Estado do Rio de Janeiro (FAPERJ, grants E-26/203.037/2016 and E-26/201.451/2014), Conselho Nacional de Desenvolvimento Científico e Tecnológico (CNPq, grant 305940/2018-0), and Coordenação de Aperfeiçoamento de Pessoal de Nível Superior Programa de Excelência Acadêmica-Finance Code 001 (CAPES ProEx, grant 23038.002486/2018-26).

\section{DECLARATION OF CONFLICT OF INTERESTS}

The authors declare no conflict of interest. The founding sponsors had no role in the design of the study; in the collection, analyses, or interpretation of data; in the writing of the manuscript, and in the decision to publish the results.

\section{AUTHORS' CONTRIBUTIONS}

The authors contributed equally to the manuscript.

\section{REFERENCES}

ADEYEMI, A. I., et al. Bacterial bloodstream infections in HIVinfected adults attending a Lagos teaching hospital. J Health Popul Nutr, v.28, n.4, p.318-326, 2010. Available from: <http:// www.ncbi.nlm.nih.gov/pmc/articles/PMC2965322>. Accessed: Feb. 27, 2019.

BACK-BRITO, G.N., etal.Staphylococcus spp.,Enterobacteriaceae and Pseudomonadaceae oral isolates from Brazilian HIV-positive patients. Correlation with CD4 cell counts and viral load. Arch Oral Biol, v.56, n.10, p.1041-6, 2011. Available from: <http:// www.ncbi.nlm.nih.gov/pubmed/21420663>. Accessed: Feb. 27, 2019. doi: 10.1016/j.archoralbio.2011.02.016.

BARKEMA, H. W., et al. Invited Review: The role of cow, pathogen, and treatment regimen in the therapeutic success of bovine Staphylococcus aureus mastitis. J Dairy Sci, v.89, n.6, p.1877-95, 2006. Available from: <http://www.ncbi.nlm.nih.gov/ pubmed/16702252>. Accessed: Feb. 27, 2019. doi: 10.3168/jds. S0022-0302(06)72256-1.

BECKER, K., et al. Coagulase-negative staphylococci. Clin Microbiol Rev, v.27, n.4, p.870-926, 2014. Available from: $<$ http://www.ncbi.nlm.nih.gov/pubmed/25278577>. Accessed: Feb. 27, 2019. doi: 10.1128/CMR.00109-13.

CATANO, J. C., et al. Bacterial contamination of clothes and environmental items in a third-level hospital in Colombia. Interdiscip Perspect Infect Dis, v.2012, p.507640, 2012. Available from: $\quad<$ http://www.ncbi.nlm.nih.gov/pubmed/22536231> Accessed: Feb. 27, 2019. doi: 10.1155/2012/507640.

DUBOI, D., et al. Identification of a variety of Staphylococcus species by matrix-assisted laser desorption ionization-time of flight mass spectrometry. J Clin Microbiol, v.48, n.3, p.941-945, 2010. Available from: <https://www.ncbi.nlm.nih.gov/pmc/articles/PMC2832446/> Accessed: Apr. 1, 2019. doi: 10.1128/JCM.00413-09.

ROSSI, C.C., et al. The oral microbiota of domestic cats harbors a wide variety of Staphylococcus species with zoonotic potential. Vet Microbiol, v.201, p.136-140, 2017. Available from: <https:// www.ncbi.nlm.nih.gov/pubmed/28284599> Accessed: Apr. 1, 2019. doi: 10.1016/j.vetmic.2017.01.029.

SANTOS, D. C., et al. Staphylococcus chromogenes, a coagulasenegative Staphylococcus species that can clot plasma. J Clin Microbiol, v.54, n.5, p.1372-1375, 2016. Available from: <https:// www.ncbi.nlm.nih.gov/pmc/articles/PMC4844742> Accessed: Feb. 27, 2019. doi: 10.1128/jcm.03139-15

SANTOS, O. C., et al. Identification of coagulase-negative staphylococci from bovine mastitis using RFLP-PCR of the groEL gene. Vet Microbiol, v.130, n.1-2, p.134-40. 2008. Available from: $<$ http://www.ncbi.nlm.nih.gov/pubmed/18295414>. Accessed: Feb. 27, 2019. doi: 10.1016/j.vetmic.2007.12.009.

SILVA, M.B., et al. An evaluation of matrix-assisted laser desorption ionization time-of-flight mass spectrometry for the identification of Staphylococcus pseudintermedius isolates from canine infections. J Vet Diagn Invest, v.27, n.2, p. 231-255, 2015. Available from: <https:/www.ncbi.nlm.nih.gov/pubmed/25680922>. Accessed: Apr. 1, 2019. doi: 10.1177/1040638715573297.

TOMAZI, T., et al. Identification of coagulase-negative staphylococci from bovine intramammary infection by matrixassisted laser desorption ionization-time of flight mass spectrometry. J Clin Microbiol, v.52, n.5, p.1658-63. 2014. Available from: $<$ http://www.ncbi.nlm.nih.gov/pubmed/24622096>. Accessed: Feb. 27, 2019. doi: 10.1128/JCM.03032-13.

TONG, S. Y., et al. Staphylococcus aureus infections: epidemiology, pathophysiology, clinical manifestations, and management. Clin Microbiol Rev, v.28, n.3, p.603-61. 2015. Available from: <http:// www.ncbi.nlm.nih.gov/pubmed/26016486>. Accessed: Feb. 27, 2019: 10.1128/CMR.00134-14.

VANDERHAEGHEN, W., et al. Invited review: effect, persistence, and virulence of coagulase-negative Staphylococcus species associated with ruminant udder health. J Dairy Sci, v.97, n.9, p.5275-93. 2014. Available from: <http://www.ncbi.nlm. nih.gov/pubmed/24952781>. Accessed: Feb. 27, 2019: 10.3168/ jds.2013-7775.

ZEMOURI, C., et al. A scoping review on bio-aerosols in healthcare and the dental environment. PLoS One, v.12, n.5, p.e0178007. 2017. Available from: <http://www.ncbi.nlm.nih. gov/pubmed/28531183>. Accessed: Feb. 27, 2019. doi: 10.1371/ journal.pone.0178007.

ZHENZHEN, D., et al. An alarming presence of methicillinresistant Staphylococcus aureus in a major hospital in the Henan province, China: A five-year observation. Asian Pac J Health Sci, v.5, n.1, p.111-113. 2018. Accessed: Feb. 27, 2019. doi: 10.21276/ apjhs.2018.5.1.27.

ZHU, W., et al. Evaluation of the Biotyper MALDI-TOF MS system for identification of Staphylococcus species. J Microbiol Methods, v.117, p.14-7. 2015. Available from: <http://www.ncbi. nlm.nih.gov/pubmed/26183765>. Accessed: Feb. 27, 2019. doi: 10.1016/j.mimet.2015.07.014. 